Article

\title{
Enhancement of Oxygen Reduction and Mitigation of Ionomer Dry-Out Using Insoluble Heteropoly Acids in Intermediate Temperature Polymer-Electrolyte Membrane Fuel Cells
}

\author{
Alessandro Stassi, Irene Gatto, Ada Saccà, Vincenzo Baglio and Antonino S. Aricò * \\ CNR-ITAE Institute of Advanced Energy Technologies "Nicola Giordano", \\ Via Salita S. Lucia sopra Contesse 5, 98126 Messina, Italy; E-Mails: stassi@itae.cnr.it (A.S.); \\ gatto@itae.cnr.it (I.G.); sacca@itae.cnr.it(A.S.); baglio@itae.cnr.it (V.B.) \\ * Author to whom correspondence should be addressed; E-Mail: arico@itae.cnr.it; \\ Tel.: +39-090-624237; Fax: +39-090-624247.
}

Academic Editor: Vladimir Gurau

Received: 15 June 2015 / Accepted: 24 July 2015 / Published: 30 July 2015

\begin{abstract}
The use of $\mathrm{Cs}_{0.5} \mathrm{H}_{0.5} \mathrm{PW}_{12} \mathrm{O}_{40}$ insoluble salt as a superacid promoter in the catalyst layer of a polymer electrolyte membrane fuel cell (PEMFC) has been investigated. An increase of performance has been recorded at intermediate temperatures $\left(110-130{ }^{\circ} \mathrm{C}\right)$ and under low relative humidity (R.H.). The promoter appears to mitigate the ionomer dry-out effects in the catalytic layer and produces an increase of the extent of the catalyst-electrolyte interface as demonstrated by cyclic voltammetry analysis. These effects are also corroborated by a significant decrease of polarization resistance at intermediate temperatures. Such characteristics have been demonstrated for a conventional membrane-electrode assembly based on a Pt-Co alloy and a Nafion 115 membrane.
\end{abstract}

Keywords: polymer electrolyte membrane fuel cell (PEMFC); heteropoly acids; $\mathrm{Cs}_{0.5} \mathrm{H}_{0.5} \mathrm{PW}_{12} \mathrm{O}_{40}$; intermediate temperature; oxygen reduction

\section{Introduction}

Advances in fuel cell technology demand a reduction of costs, a decrease of Pt loading and optimization of catalyst utilization [1,2]. In addition, for an easy thermal and water management, the automotive fuel cell market requires an increase of the working temperature almost up to $130{ }^{\circ} \mathrm{C}$ 
and operation with low relative humidity (R.H.), less than 50\%. This could favor the large diffusion of polymer electrolyte membrane fuel cells (PEMFCs) [3,4].

In the last few years, the research on electrocatalysts has been mainly focused on the reduction of platinum loading, enhancement of intrinsic activity and on increase of performance through a better platinum utilization. Various approaches have been pursued, including the use of binary and ternary Pt-alloy catalyst development, e.g., PtCo, PtNi, PtCoCr, PtCoMn [2,5-10]. These alloys lead to an increase of the mass activity with respect to the conventional $\mathrm{Pt} / \mathrm{C}$ catalyst and consequently to a decrease of the platinum content. Despite the interesting performances obtained by using such catalysts, an improvement of the oxygen reduction reaction (ORR) kinetic is still necessary at intermediate temperatures $\left(100-130{ }^{\circ} \mathrm{C}\right)$ and under low relative humidity $(50 \%$ R.H. or less). These harsh operative conditions affect the oxygen reduction rate negatively due to a decrease of the proton transport rate, caused by dehydration and oxygen solubility at the electrode-electrolyte interface [3]. An approach to mitigate these effects is to add into the cathode layer an oxide-based promoter. Recent studies $[11,12]$ have focused on the use of different oxides (e.g., oxide species of $\mathrm{Ti}, \mathrm{Zr}$ and $\mathrm{Ce}$ ) in the cathode catalyst layer as promoters for the ORR.

It has not been clearly demonstrated which are the prevailing effects that occur when an oxide or an alternative promoter are added into the cathode layer. Shim et al. [11] hypothesized that the increase of performance due to the presence of the oxide materials near the Pt sites is related to their capability to weaken the strength of oxygen adsorption on the Pt surface. Xu et al. [12] reported that the metal oxides can be utilized as an oxygen storage material incorporated into the catalyst layer, producing an enhancement of the fuel cell performance.

The increase of oxygen solubility in heteropoly acid (HPA)-based electrolytes for fuel cell application was observed several years ago in our laboratory with relevant effects on the oxygen reduction process on $\mathrm{Pt}$ at room temperature [13-15].

According to these evidences, we have utilized an insoluble HPA salt of cesium, $\mathrm{Cs}_{2.5} \mathrm{H}_{0.5} \mathrm{PW}_{12} \mathrm{O}_{40}$ $(\mathrm{CsPW})$, in the cathode catalytic layer of a PEMFC operating at intermediate temperature. Similar CsPW salts were previously investigated as a filler in membranes for fuel cell application [16-18]. Water insolubility or high stability in an acid environment are characteristics of CsPW salts and similar materials [19]. These compounds, used as fillers in the electrode or the electrolyte of a PEMFC, can give rise to a better proton conductivity and an increase of water uptake [16-21]. These characteristics are useful for the cathode process, which is the rate determining step, especially when the process is carried out under conditions of low humidification and at temperatures higher than $100{ }^{\circ} \mathrm{C}$.

A critical aspect of intermediate temperature operation is the so-called ionomer dry-out in the catalytic layer, which causes a decrease of proton transport with a dramatic voltage loss already at low currents [22]. Due to their intrinsic super-acid properties, heteropoly acid-based compounds can mitigate such constraints. In addition, the high oxygen solubility in the heteropoly acid compound should increase the oxygen availability close to the catalytic sites at the catalyst-electrolyte interface with an effect similar to metal oxide promoters [13].

Recently, Dsoke et al. [23], using a rotating disk study, reported on the use of CsPW as a support for a Pt catalyst showing enhanced properties at low temperature. However, to our best knowledge, this salt has not yet been investigated as an electro-catalyst promoter in the catalytic layer of a membrane electrode assembly (MEA) to increase the performance under intermediate temperature 
operation. Platinized heteropoly acid compounds in combination with the addition of electronic conductors to catalytic layers have been studied for low temperature fuel cell applications, showing promising catalytic properties [24]. The purpose of this work is thus to investigate the use of the CsPW salt in the cathode catalytic layer and its effects on the performance of our benchmark catalyst based on 50 wt.\% $\mathrm{Pt}_{3} \mathrm{Co} / / \mathrm{Ketjenblack}(\mathrm{PtCo} / \mathrm{C})[25,26]$. In order to investigate the effect of the promoter, a comparison with the bare $\mathrm{PtCo} / \mathrm{C}$ catalyst-based catalytic layer has been carried out.

\section{Results and Discussion}

\subsection{Physico-Chemical Characterization}

The X-ray diffraction (XRD) pattern of the promoter is shown in Figure 1. The promoter showed the conventional structure of CsPW salts. The crystallite size calculated by using the Debye-Sherrer equation was about $18 \mathrm{~nm}$. The characteristics of the $\mathrm{PtCo} / \mathrm{C}$ catalyst were reported in a previous work [26]. In brief, the catalyst showed a single ordered primitive cubic (L12) phase. Line broadening analysis of the (2 20 ) reflection showed a crystallite size of $3.3 \mathrm{~nm}$ for the PtCo catalyst. The X-ray fluorescence (XRF) analysis of the overall catalyst gave an atomic ratio Pt:Co of 3.0.

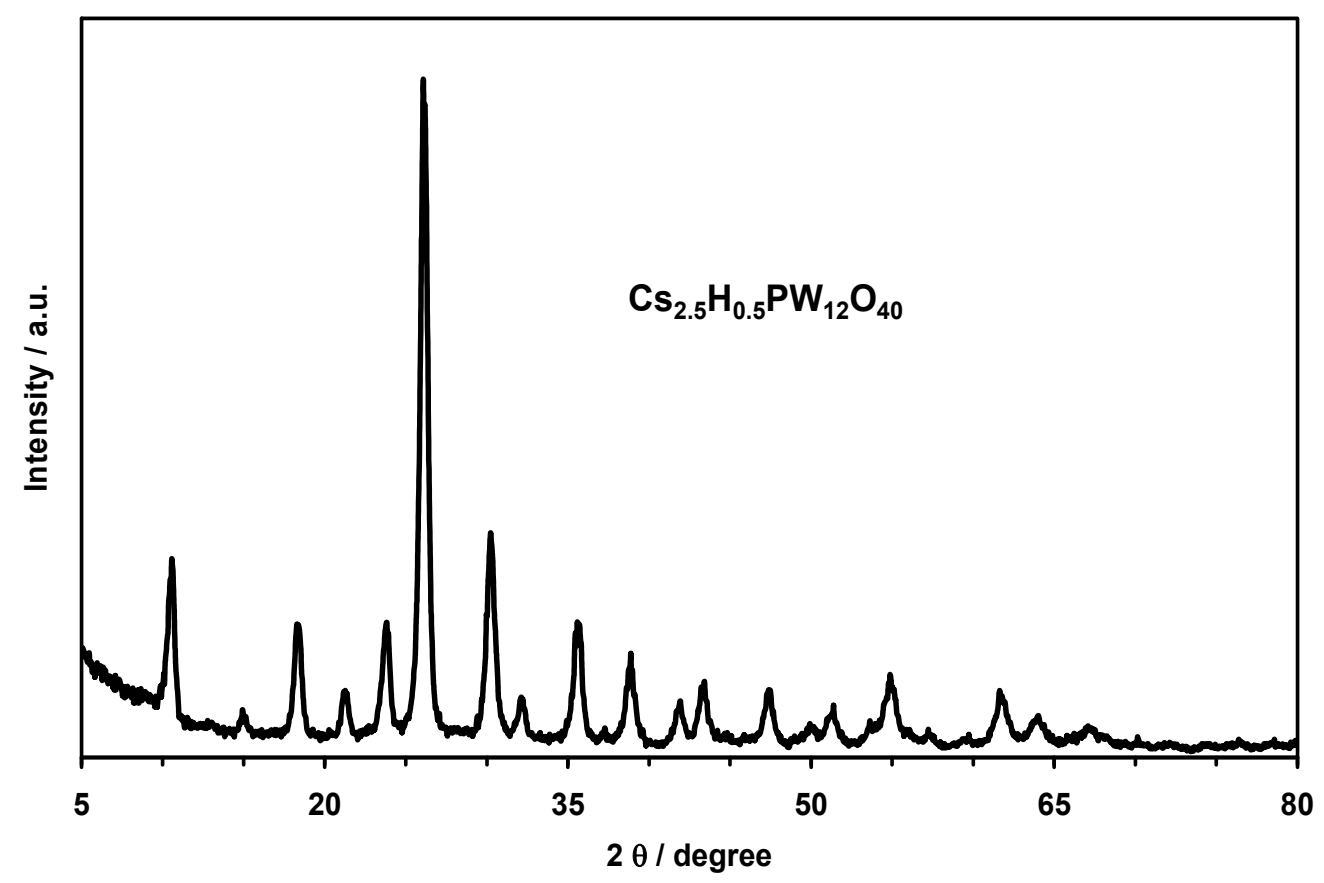

Figure 1. X-ray diffraction of the promoter compound.

The CsPW promoter, alone and in the catalytic layer, was analyzed by scanning electron microscopy and energy dispersive X-rays analysis (SEM-EDX) to evaluate the morphology (Figure 2). The micrographs show a non-homogeneous distribution of the particle size with different dimensions comprised between $50 \mathrm{~nm}$ and $900 \mathrm{~nm}$ (Figure 2). 


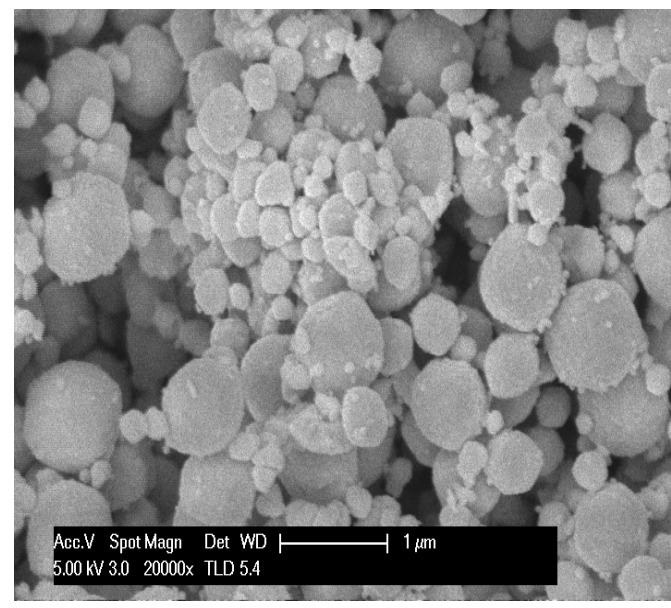

(a)

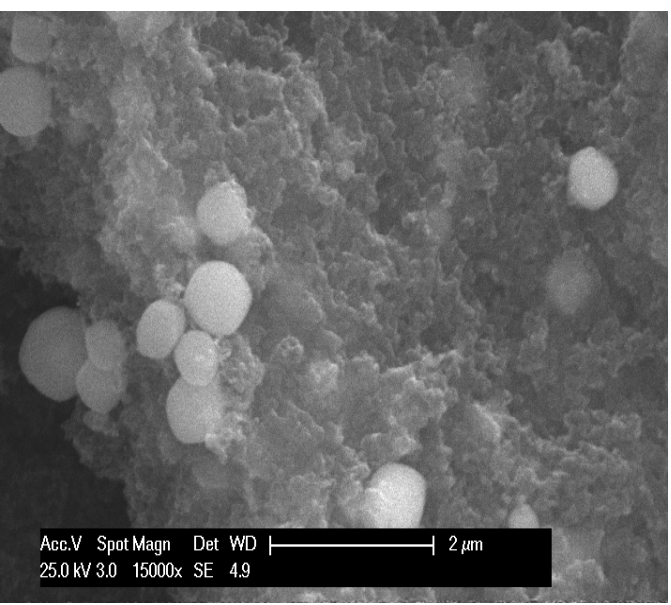

(b)

Figure 2. Morphology of the promoter compound; (a) alone; (b) dispersed in the catalytic layer.

\subsection{Electrochemical Characterization}

Polarization curves were first carried out at $80{ }^{\circ} \mathrm{C}$ and under full humidification using an air feed. The cathodes'/MEAs' performances with and without the promoter are reported in Figure 3.

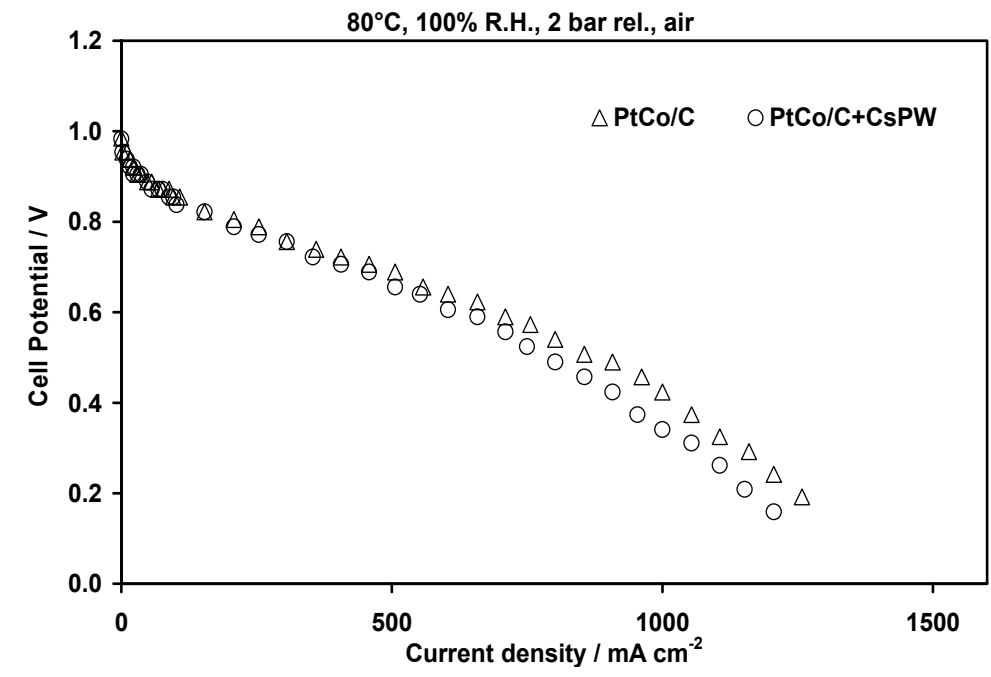

Figure 3. Polarization curves for the promoter-based and the bare catalytic layers at $80{ }^{\circ} \mathrm{C}$, $100 \%$ relative humidity (R.H.), air feed, 2 bar relative (rel.).

It is possible to observe that the presence of promoter produces no relevant effect at $80{ }^{\circ} \mathrm{C}$ and $100 \%$ R.H., but rather, an increase of the flooding effect at high current densities using an air feed with a slight decrease of performance in the mass transport region. This effect could be attributed to the fact that the hygroscopic properties of the promoter lead to an increase of water retention in the catalytic layer (flooding effect) at high current densities. In fact, a similar effect was recorded for the water uptake when the CsPW was used in a membrane [16-18]. Figure 4 shows the effect of temperature on the polarization curves obtained with oxygen feed under full humidification for bare and promoter-modified cathodes. 


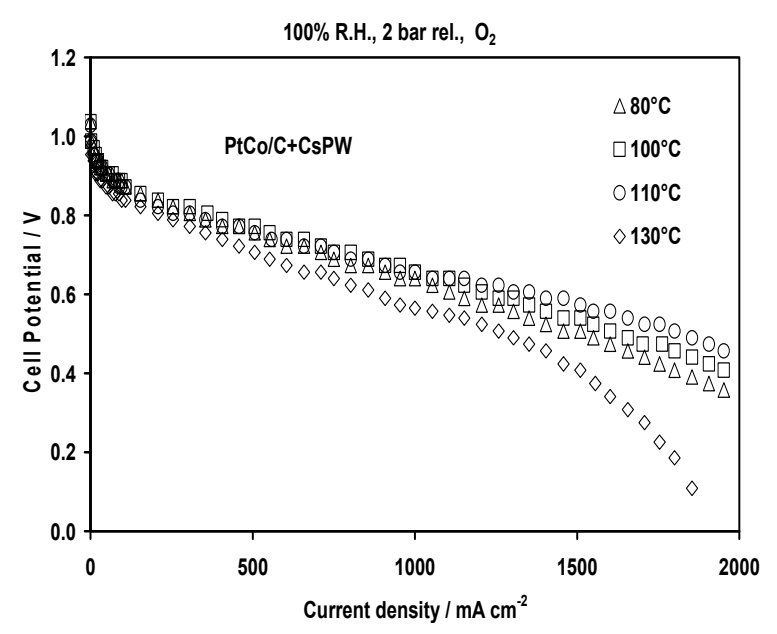

(a)

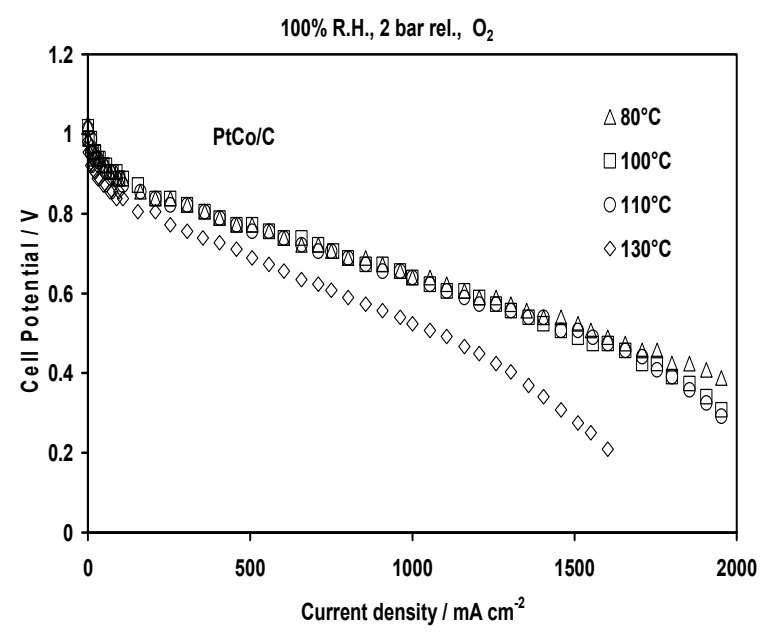

(b)

Figure 4. Effect of temperature on the polarization curves of promoter-based (a) and the bare (b) catalytic layers. 100\% R.H., $\mathrm{O}_{2}$ feed, 2 bar rel.

It is observed that the effect of the promoter becomes relevant with the increase of temperature. The best results using the promoter are achieved at $110^{\circ} \mathrm{C}$ (Figure 4a); whereas without the promoter, no significant differences were recorded with the increase of temperature up to $110{ }^{\circ} \mathrm{C}$ (Figure $4 \mathrm{~b}$ ). By comparing the polarization curves carried out at $130{ }^{\circ} \mathrm{C}$ and $100 \%$ R.H. with $\mathrm{O}_{2}$ (Figure 5), even if the performances obtained at $130{ }^{\circ} \mathrm{C}$ are in general lower than those at lower temperatures (Figure 4), it is evident that the MEA containing the promoter performs definitively better than that based on the $\mathrm{PtCo} / \mathrm{C}$ catalyst only.

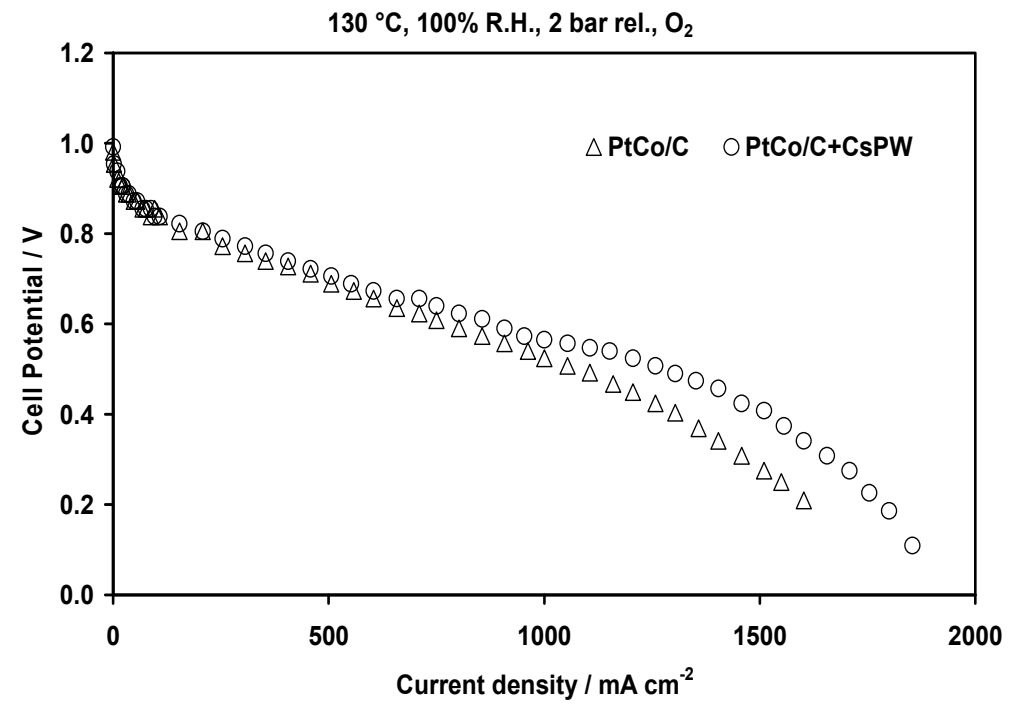

Figure 5. Comparison of the polarization curves for the promoter-based and the bare catalytic layers at $130{ }^{\circ} \mathrm{C}, 100 \%$ R.H., $\mathrm{O}_{2}$ feed, 2 bar rel.

The moderate decrease of performance recorded at $130{ }^{\circ} \mathrm{C}, 100 \%$ R.H., could be due to the fact that at 2 bar relative (rel.), there is still a small amount of liquid water present inside the MEA, but the negative effect on proton conductivity caused by dehydration is, however, present [27]. In any case, it is evident that the dehydration effect is mitigated in the presence of promoter. 
To investigate the influence of promoter on the resistance characteristics of the MEA, AC impedance analysis was carried out at $130{ }^{\circ} \mathrm{C}, 100 \%$ R.H., at $850 \mathrm{mV}$ and $650 \mathrm{mV}$, respectively (Figure 6). Ohmic resistance $\left(R_{\mathrm{S}}\right)$ was derived from the high-frequency intercept. Polarization resistance $\left(\mathrm{R}_{\mathrm{p}}\right)$ was obtained as the difference between the low-frequency intercept $\left(R_{\mathrm{t}}\right)$ and the ohmic resistance $\left(R_{\mathrm{p}}=R_{\mathrm{t}}-R_{\mathrm{s}}\right)$. In Figure 6, it is evident that the presence of the promoter in the cathode does not affect the ohmic resistance (about $0.15 \mathrm{~cm}^{2}$ ), whereas for the polarization resistances, a significant reduction was recorded. In fact, the $\mathrm{R}_{\mathrm{p}}$ values measured at $850 \mathrm{mV}$ were of $0.60 \mathrm{~cm}^{2}$ and $0.85 \mathrm{~cm}^{2}$, while at $650 \mathrm{mV}$, they were $0.13 \mathrm{~cm}^{2}$ and $0.22 \mathrm{~cm}^{2}$ in the presence and in the absence of the promoter, respectively.

$130^{\circ} \mathrm{C}, 100 \%$ R.H., 2 bar rel., $\mathrm{O}_{2}$, @ 850mV

$130^{\circ} \mathrm{C}, 100 \%$ R.H., 2 bar rel., $\mathrm{O}_{2}$, @ $650 \mathrm{mV}$

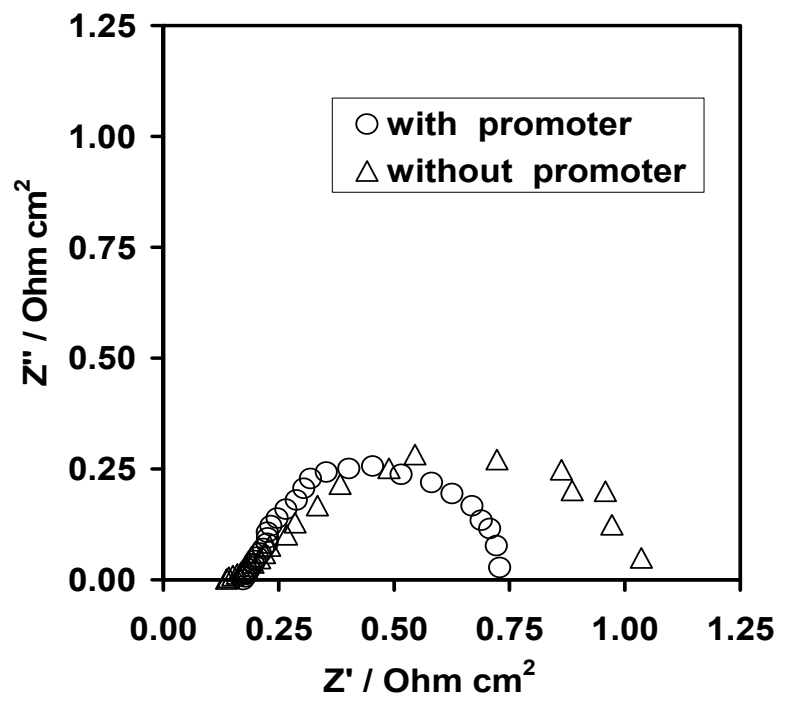

(a)

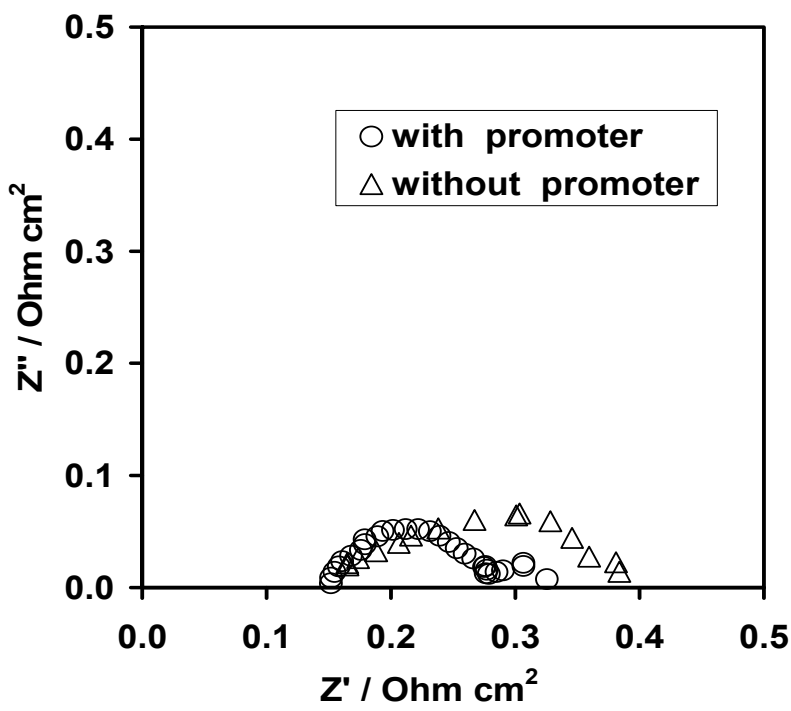

(b)

Figure 6. AC impedance spectra for the promoter-based and the bare membrane electrode assemblies (MEAs) at $130{ }^{\circ} \mathrm{C}, 100 \%$ R.H., $\mathrm{O}_{2}$ feed, 2 bar rel., at a cell voltage of: (a) $0.85 \mathrm{~V}$; (b) $0.65 \mathrm{~V}$.

When the R.H. was decreased to $33 \%$, the effect of the promoter became more relevant even at $80{ }^{\circ} \mathrm{C}$ (Figure 7). However, the gain in performance was observed essentially at high current, where the water production is greater. The polarization curves (Figure 8) carried out at $130{ }^{\circ} \mathrm{C}$ and low R.H. (33\%) show that the promoter provides a significant increase of performances under such harsh conditions. However, under these conditions, the effect of Nafion membrane dry-out is dominant.

All of the results reported above show that the presence of the promoter on the cathode side produces an effect on the MEA performance, especially in the medium and high current range, in particular under high temperature and low humidification conditions. It is pointed out that the voltage range of interest for a practical utilization of a PEMFC is between $0.6 \mathrm{~V}$ and $0.7 \mathrm{~V}$, where the efficiency of the entire system is maximized. The enhancement in terms of performance due to the presence of the promoter could be caused by different effects, such as a better oxygen solubility at the interface [13], high proton conductivity and an increase of water content/water retention in the catalytic layer [16-18] by the effect of the hygroscopic properties. The latter effect reduces the dry-out constraints, especially under extreme conditions of high temperature and low humidification. 
$80{ }^{\circ} \mathrm{C}, 33 \%$ R.H., 2 bar rel., $\mathrm{O}_{2}$

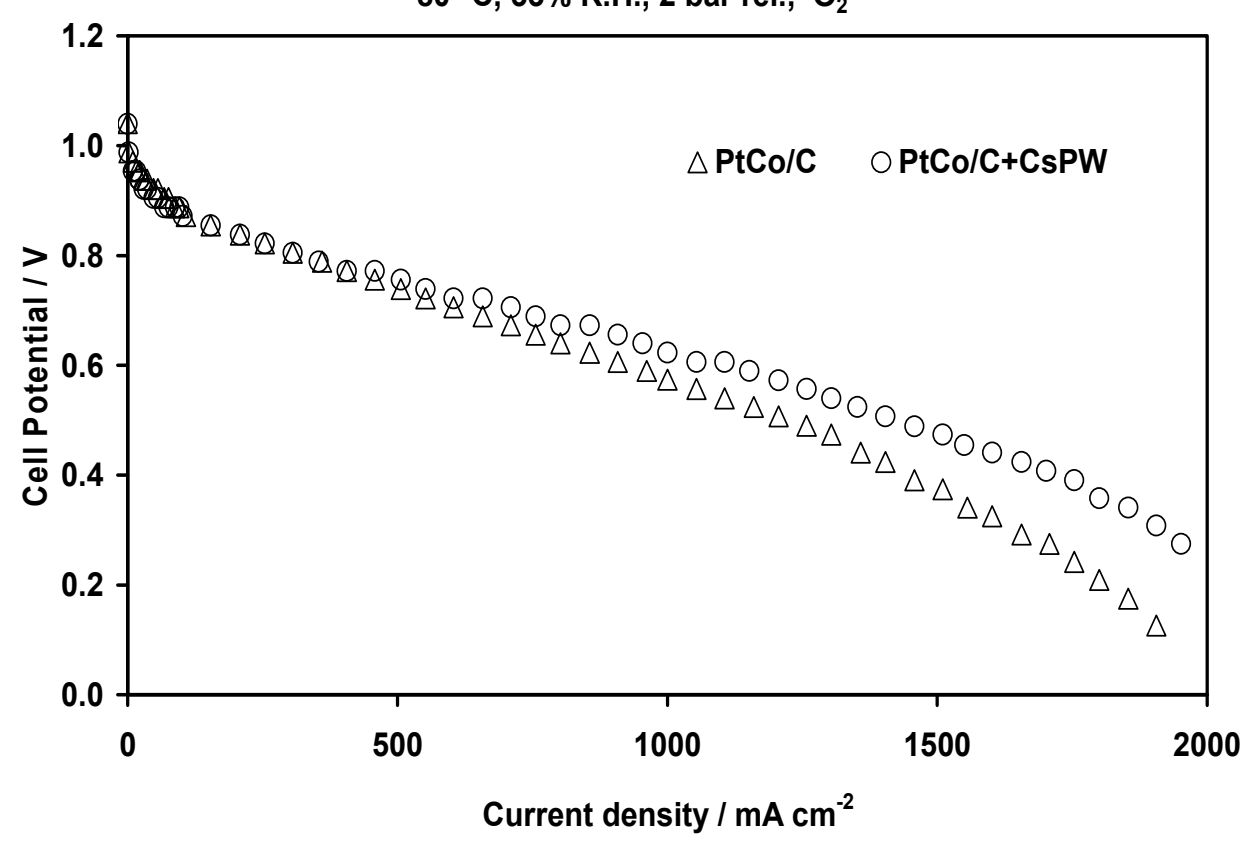

Figure 7. Polarization curves for the promoter-based and the bare MEAs at $80{ }^{\circ} \mathrm{C}, 2$ bar rel., in the presence of low relative humidity $(33 \%$ R.H.).

$130^{\circ} \mathrm{C}, 33 \%$ R.H., 2 bar rel. $O_{2}$

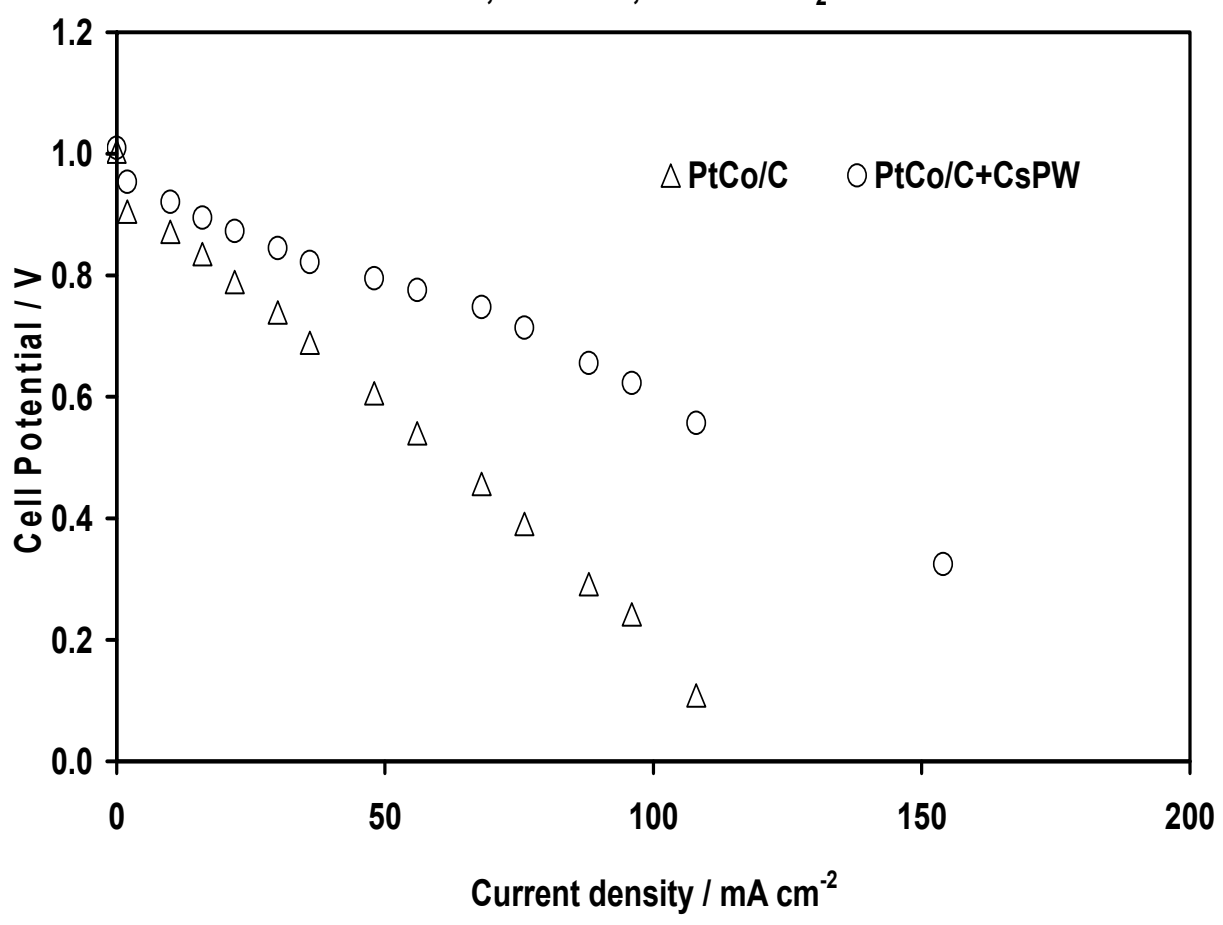

Figure 8. Polarization curves for the promoter-based and the bare MEAs under harsh operating conditions of $130{ }^{\circ} \mathrm{C}$, low relative humidity (33\% R.H.), oxygen feed, 2 bar rel.

Even if no significant changes in terms of mass activity at conventional temperatures were recorded in the polarization curves of both cathodes with and without CsPW salt, the cyclic voltammetry carried out at $80{ }^{\circ} \mathrm{C}$ and full humidification (Figure 9) clearly shows a change in the adsorption profile of $\mathrm{OH}-$ and $\mathrm{H}$-species in the presence of the promoter. 


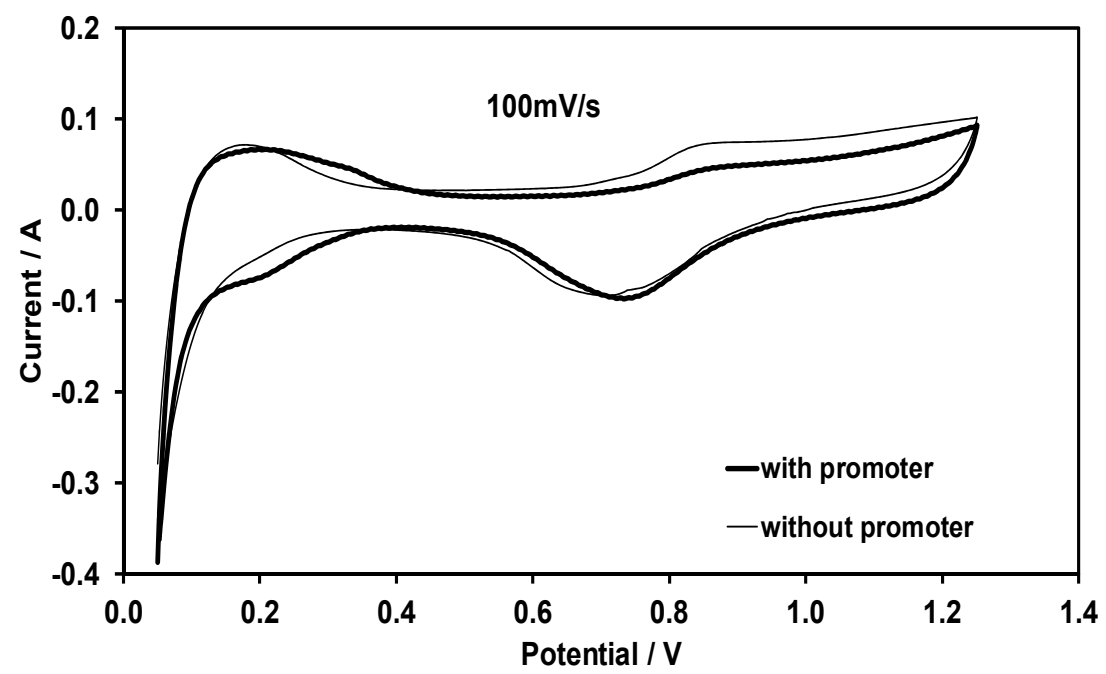

Figure 9. Cyclic voltammetry analysis at $80{ }^{\circ} \mathrm{C}, 100 \%$ R.H. for the PtCo-based catalytic layer with and without promoter; sweep rate $100 \mathrm{mV} \cdot \mathrm{s}^{-1}$.

An increase in terms of active electrochemical surface area (ECSA) from $49 \mathrm{~m}^{2} / \mathrm{g}$ for PtCo/C catalyst to $55 \mathrm{~m}^{2} / \mathrm{g}$ when the promoter is added to the cathode layer is observed. In addition, a shift towards higher potentials for the Pt oxide reduction peak is observed with the promoter. The latter could be related to a synergistic effect of the promoter and the catalyst on enhancing oxygen reduction. This is also corroborated by the decrease of the polarization resistance previously observed by AC impedance analysis (Figure 6).

The positive role of the heteropoly acid promoter under high temperature $\left(110^{\circ} \mathrm{C}\right)$ and low R.H. $(33 \%)$ appears clearly evident from the analysis of both ohmic and polarization resistances in the AC impedance spectra recorded at a cell potential of $0.65 \mathrm{~V}$ (Figure 10). This indicates that the presence of the heteropoly acid promoter is beneficial, both in terms of enhanced proton conduction in the cathode layer (lower dry-out effects) and improved electro-catalytic activity.

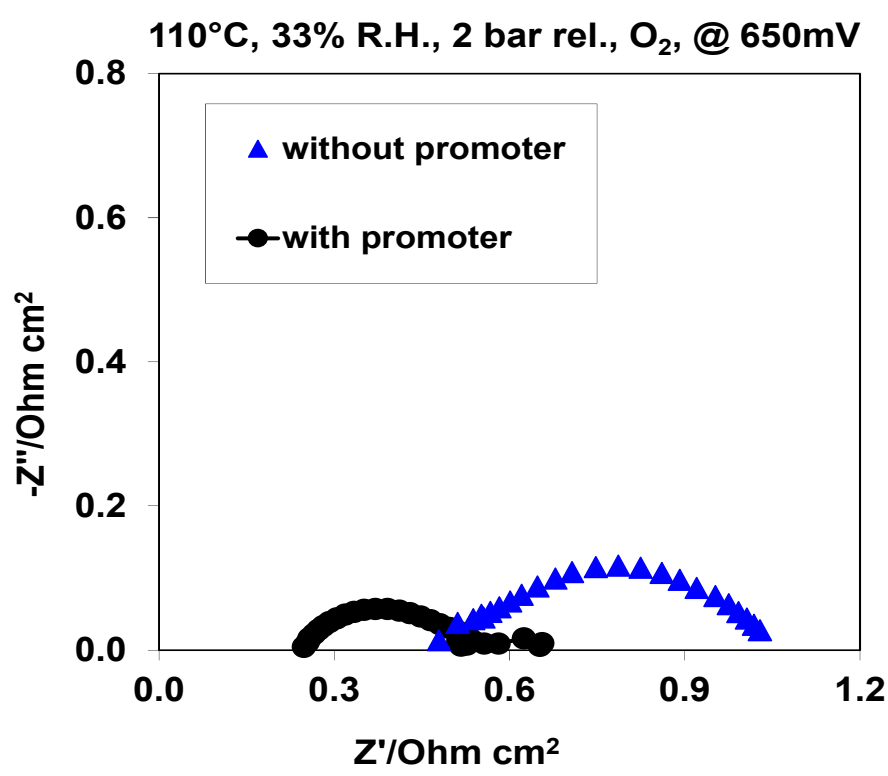

Figure 10. AC impedance spectra at $110{ }^{\circ} \mathrm{C}, 33 \%$ R.H., $0.65 \mathrm{~V}$, for the PtCo-based catalytic layer with and without promoter. 
Further improvements are necessary in terms of promoter particle size to offer a better interface with the electro-catalyst. We are currently working on this aspect with the aim of further enhancing the performance under high temperature and low R.H.

\section{Experimental Section}

\subsection{Promoter Preparation}

A proper amount of $\mathrm{H}_{3} \mathrm{PW}_{12} \mathrm{O}_{40}$ (Aldrich, Milan, Italy) was dissolved in $100 \mathrm{~mL}$ of deionized water at $50{ }^{\circ} \mathrm{C}$ under vigorous stirring. Then, a solution containing the proper amount of $\mathrm{Cs}_{2} \mathrm{SO}_{4}$ (Aldrich, Milan, Italy) previously dissolved in $50 \mathrm{~mL}$ of deionized water was added drop by drop to the solution containing the phosphotungstic acid. The obtained solution was kept at $50{ }^{\circ} \mathrm{C}$ for $1 \mathrm{~h}$ and afterwards was cooled at room temperature and maintained under vigorous stirring for a further $24 \mathrm{~h}$. Then, the stirring was stopped, and the salt was allowed to precipitate for $24 \mathrm{~h}$. Finally, the solution was filtered, washed with abundant deionized water and dried in an oven under high vacuum at $80{ }^{\circ} \mathrm{C}$ for a night.

\subsection{Catalyst Preparation}

A 50 wt.\% $\mathrm{PtCo} / \mathrm{C}$ catalyst with nominal alloy composition $\mathrm{Pt}_{3} \mathrm{Co}_{1}$ (atomic, at.) was prepared by incipient wetness of cobalt nitrate on an amorphous $\mathrm{PtO}_{x} / \mathrm{C}$ catalyst [28]. The concentration of $\mathrm{Co}\left(\mathrm{NO}_{3}\right)_{2}$ was adjusted to achieve a $\mathrm{Pt} / \mathrm{Co}$ atomic ratio of about $3: 1$ in the final catalysts. The $\mathrm{PtO}_{x} / \mathrm{C}$ was prepared by using a sulfite complex route [28]. Ketjenblack EC (KB) carbon black with a Brunauer Emmett Teller (BET) surface area of $850 \mathrm{~m}^{2} \cdot \mathrm{g}^{-1}$ was used as the conductive support for the PtCo nanoparticles. After the cobalt impregnation step, a high temperature carbothermal reduction in inert (Ar) atmosphere was carried out to form the carbon-supported PtCo alloy. A specific temperature was selected for the thermal reduction $\left(800{ }^{\circ} \mathrm{C}\right)$. A pre-leaching procedure at $80{ }^{\circ} \mathrm{C}$ in $0.5 \mathrm{M} \mathrm{HClO}_{4}$ was carried out for the PtCo catalyst after the thermal reduction to remove any un-alloyed Co atoms in the outermost layer.

\subsection{Physico-Chemical Analysis}

The catalyst and the promoter were characterized by XRD using a Philips X-pert 3710 X-ray diffractometer (Almelo, the Netherlands) with $\mathrm{Cu} \mathrm{Ka}$ radiation operating at $40 \mathrm{kV}$ and $30 \mathrm{~mA}$. The peak profile of the $(220)$ reflection in the cubic structure of the Pt-alloy catalyst and the peak profile of the ( $\left.\begin{array}{ll}2 & 2\end{array}\right)$ reflection in the structure of CsPW, respectively, were analyzed by using the Marquardt algorithm. The crystallite size were thus determined by the Debye-Scherrer equation [29]. Instrumental broadening was determined by using a standard platinum sample. XRF analysis of the catalyst was carried out by a Bruker AXS S4 Explorer spectrometer (Karlsruhe, Germany) operating at a power of $1 \mathrm{~kW}$ and equipped with a $\mathrm{Rh} \mathrm{X}$-ray source, a LiF 220 crystal analyzer and a $0.12^{\circ}$ divergence collimator. The Pt/Co atomic ratio for the alloy was determined by XRD analysis using Vegard's law. The overall $\mathrm{Pt} / \mathrm{Co}$ ratio in the catalyst was determined by XRF. The total metal content in the catalysts was determined by burning the carbon support in a thermal gravimetry experiment up to $950{ }^{\circ} \mathrm{C}$ in air and subsequent XRD analysis. SEM-EDX analysis of the promoter was carried out by an FEI XL-30 FEG instrument (Eindhoven, The Netherlands). 


\subsection{Electrochemical Studies}

The electrodes were prepared according to the procedure described in a previous report [27]; they consisted of carbon cloth backings, diffusion and catalytic layers. For the bare cathode, the $\mathrm{PtCo} / \mathrm{C}$ catalyst was prepared by mixing $33 \mathrm{wt} . \%$ Nafion ionomer and $67 \mathrm{wt} . \%$ catalyst; while for the promoter-modified cathode, the catalytic layer was prepared by mixing $33 \mathrm{wt} . \%$ Nafion ionomer, $60 \mathrm{wt} . \%$ catalyst and $7 \mathrm{wt} . \%$ promoter. This is to keep constant the weight ratio (catalyst + promoter/ionomer). A Nafion 115 membrane $(\sim 120 \mu \mathrm{m})$ was preferred to thinner perfluorosulphonic acid (PFSA) membranes in order to reduce the effect of $\mathrm{H}_{2}$ crossover, which may affect the in situ determination of the mass activity at $0.9 \mathrm{~V}$ RHE (reversible hydrogen electrode) and the cyclic voltammetry profile. The overall fuel cell performance is of course affected by the ohmic loss, which is related to the membrane thickness. In the various MEAs, the anode was maintained constant, whereas the cathode was varied as described above. In all of the tests, the total Pt loading was $0.3 \mathrm{mg} \cdot \mathrm{cm}^{-2}$.

MEAs were formed by a hot pressing procedure and subsequently installed in a fuel cell test fixture. This was connected to a fuel cell test station including an HP6060B (Renton, WA, USA) electronic load and an AUTOLAB metrohm potentiostat/galvanostat equipped with a $20 \mathrm{~A}$ current booster. The humidifier's temperature was varied with respect to the cell temperature to change the R.H. The cell temperature was measured by a thermocouple embedded in the cathodic graphite plate, close to the MEA. Steady-state galvanostatic polarization experiments in PEMFC were performed in the presence of $\mathrm{H}_{2}-\mathrm{O}_{2}$ /air at various temperatures and R.H., while the pressure was kept constant at 2 bar rel. Electrochemical data were not corrected for gas cross-over. Cyclic voltammetry studies were carried out at $80^{\circ} \mathrm{C}$. In this experiment, hydrogen was fed to the anode that operated as both the counter and reference electrode, whereas nitrogen was fed to the working electrode. The sweep rate was $100 \mathrm{mV} \cdot \mathrm{s}^{-1}$. The impedance measurements were performed in a frequency range between $1 \mathrm{MHz}$ and $0.01 \mathrm{~Hz}$ by frequency sweeping in single sine mode.

Polarization measurements were carried out starting from low R.H. The R.H. was kept constant, and the temperature was increased. A continuous set of measurements at constant R.H. and covering the full temperature range required one day. The conditioning time at the specific operating conditions before the test was typically $1 \mathrm{~h}$.

The R.H. was changed to the next value (increased) in a successive day and the cycle of measurements at each temperature repeated.

\section{Conclusions}

The addition of an insoluble cesium salt of phosphotungstic acid as the promoter for the oxygen reduction in PEMFCs has clearly produced an enhancement of the performance at intermediate temperature and low R.H. The promoter seems to mitigate the effects of ionomer dry-out and probably increases the oxygen solubility under harsh operative conditions. The decrease of polarization resistance and the increase of the active interface area clearly prove the positive role played by the heteropoly acid-based co-catalyst. These characteristics have been demonstrated for an MEA based on a thick Nafion membrane. However, the effect could be even more relevant for thin PFSA membrane-based MEAs with better prospects to operate at intermediate temperatures. 


\section{Acknowledgments}

The research leading to these results has received funding from the European Community's Seventh Framework Programme (FP7/2011-2014) for the Fuel Cells and Hydrogen Joint Technology Initiative under Grant Agreement No. 303452-IMPACT.

\section{Conflicts of Interest}

The authors declare no conflict of interest.

\section{References}

1. Gasteiger, H.A.; Kocha, S.S.; Sompalli, B.; Wagner, F.T. Activity benchmarks and requirements for Pt, Pt-alloy, and non-Pt oxygen reduction catalysts for PEMFCs. Appl. Catal. B Environ. 2005, 56, 9-35.

2. Jaffray, C.; Hards, G.A. Handbook of Fuel Cells-Fundamentals, Technology and Applications; Vielstich, W., Lamm, A., Gasteiger, H., Eds.; John Wiley \& Sons: Chichester, UK, 2003.

3. Srinivasan, S.; Dillon, R.; Krishnan, L.; Aricò, A.S.; Antonucci, V.; Bocarsly, A.B.; Lee, W.J.; Hsueh, K.L.; Lai, C.C.; Peng, A. Techno-Economic Challenges for PEMFCs and DMFCs Entering Energy Sector. In Proceedings of the 1st Fuel Cell Science Engineering and Technology, New York, NY, USA, 21-23 April 2003; pp. 529-536.

4. Ji, M.; Wei, Z. A Review of Water Management in Polymer Electrolyte Membrane Fuel Cells. Energies 2009, 2, 1057-1106.

5. Strasser, P.; Koh, S.; Anniyev, T.; Greeley, J.; More, K.; Yu, C.; Liu, Z.; Kaya, S.; Nordlund, D.; Ogasawara, H. Lattice-strain control of the activity in dealloyed core-shell fuel cell catalysts. Nat. Chem. 2010, 2, 454-460.

6. Debe, M.K.; Schmoeckel, A.K.; Vernstrom, G.D.; Atanasoski, R. High voltage stability of nanostructured thin film catalysts for PEM fuel cells. J. Power Sources 2006, 161, 1002-1011.

7. Wood, T.E.; Tan, Z.; Schmoeckel, A.K.; O’Neill, D.; Atanasoski, R. Non-precious metal oxygen reduction catalyst for PEM fuel cells based on nitroaniline precursor. J. Power Sources 2008, 178, 510-516.

8. Wildgoose, G.G.; Banks, C.E.; Compton, R.G. Metal Nanoparticles and Related Materials Supported on Carbon Nanotubes: Methods and Applications. Small 2006, 2, 182-193.

9. Stamenkovic, V.; Mun, B.S.; Mayrhofer, K.J.; Ross, P.N.; Markovic, N.M.; Rossmeisl, J.; Greeley, J.; Norskov, J.K. Changing the Activity of Electrocatalysts for Oxygen Reduction by Tuning the Surface Electronic Structure. Angew. Chem. 2006, 45, 2897-2901.

10. Chen, S.; Sheng, W.; Yabuuchi, N.; Ferreira, P.J.; Allard, L.F.; Yang, S.H. Origin of Oxygen Reduction Reaction Activity on "Pt $\mathrm{C}_{3} \mathrm{Co}$ " Nanoparticles: Atomically Resolved Chemical Compositions and Structures. J. Phys. Chem. C. 2009, 113, 1109-1125.

11. Shim, J.; Lee, C.R.; Lee, H.K.; Lee, J.S.; Cairns, E.J. Electrochemical characteristics of Pt-WO $/ \mathrm{C}$ and $\mathrm{Pt}-\mathrm{TiO}_{2} / \mathrm{C}$ electrocatalysts in a polymer electrolyte fuel cell. J. Power Sources 2001, 102, $172-177$. 
12. Xu, Z.; Qi, Z.; Kaufman, A. Effect of oxygen storage materials on the performance of proton-exchange membrane fuel cells. J. Power Sources 2003, 115, 40-43.

13. Giordano, N.; Aricò, A.S.; Hocevar, S.; Staiti, P.; Antonucci, P.L.; Antonucci, V. Oxygen Reduction Kinetics in Phosphotungstic Acid at Low Temperature. Electrochim. Acta 1993, 38, 1733-1741.

14. Giordano, N.; Staiti, P.; Hocevar, S.; Aricò, A.S. High performance fuel cell based on phosphotungstic acid as proton conducting electrolyte. Electrochim. Acta 1996, 41, 397-403.

15. Giordano, N.; Staiti, P.; Aricò, A.S.; Passalacqua, E.; Abate, L.; Hocevar, S. Analysis of the chemical cross-over in a phosphotungstic acid electrolyte based fuel cell. Electrochim. Acta 1997, $42,1645-1652$.

16. Xu, C.; Wu, X.; Wang, X.; Mamlouk, M.; Scott, K. Composite membranes of polybenzimidazole and cesium-salts-of heteropolyacids for intermediate temperature fuel cells. J. Mater. Chem. 2011, 21, 6014-6019.

17. Amirinejad, M.; Madaeni, S.S.; Rafiee, E.; Amirinejad, S. Cesium hydrogen salt of heteropolyacids/Nafion nanocomposite membranes for proton exchange membrane fuel cells. J. Membr. Sci. 2011, 377, 89-98.

18. Xu, C.; Wang, X.; Wu, X.; Cao, Y.; Scott, K. A Composite Membrane of Cesium Salt of Heteropolyacids/Quaternary Diazabicyclo-Octane Polysulfone with Poly (Tetrafluoroethylene) for Intermediate Temperature Fuel Cells. Membranes 2012, 2, 384-394.

19. Kourasi, M.; Wills, R.G.A.; Shah, A.A.; Walsh, F.C. Heteropolyacids for fuel cell applications. Electrochim. Acta 2014, 127, 454-466.

20. Wlodarczyk, R.; Chojak, M.; Miecznikowski, K.; Kolary, A.; Kulesza, P.J.; Marassi, R. Electroreduction of oxygen at polyoxometallate-modified glassy carbon-supported Pt nanoparticles. J. Power Sources 2006, 159, 802-809.

21. Wlodarczyk, R.; Kolary-Zurowska, A.; Marassi, R.; Chojak, M.; Kulesza, P.J. Enhancement of oxygen reduction by incorporation of heteropolytungstate into the electrocatalytic ink of carbon supported platinum nanoparticles. Electrochim. Acta 2007, 52, 3958-3964.

22. Aricò, A.S.; Di Blasi, A.; Brunaccini, G.; Sergi, F.; Dispenza, G.; Andaloro, L.; Ferraro, M.; Antonucci, V.; Asher, P.; Buche, S.; et al. High Temperature Operation of a Solid Polymer Electrolyte Fuel Cell Stack Based on a New Ionomer Membrane. Fuel Cells 2010, 10, 1013-1023.

23. Dsoke, S.; Kolary-Zurowska, A.; Zurowski, A.; Mignini, P.; Kulesza, P.J.; Marassi, R. Rotating disk electrode study of $\mathrm{Cs}_{2.5} \mathrm{H}_{0.5} \mathrm{PW}_{12} \mathrm{O}_{40}$ as mesoporous support for Pt nanoparticles for PEM fuel cells electrodes. J. Power Sources 2011, 196, 10591-10600.

24. Zhao, J.; Ukshe, A.E.; Leonova, L.S.; Chub, A.V.; Frolova, L.A.; Dobrovolsky, Y.A. Composite catalytic system based on the platinised heteropolycompounds with addition of electronic conductors for low-temperature hydrogen-air fuel cells. Int. Sc. J. Altern. Energy Ecol. 2010, 12, 37-49.

25. Aricò, A.S.; Stassi, A.; Gatto, I.; Monforte, G.; Passalacqua, E.; Antonucci, V. Surface properties of $\mathrm{Pt}$ and PtCo electrocatalysts and their influence on the performance and degradation of high-temperature polymer electrolyte fuel cells. J. Phys. Chem. C 2010, 114, 15823-15836.

26. Stassi, A.; Gatto, I.; Monforte, G.; Baglio, V.; Passalacqua, E.; Antonucci, V.; Aricò, A.S. The effect of thermal treatment on structure and surface composition of PtCo electro-catalysts for application in PEMFCs operating under automotive conditions. J. Power Sources 2012, 208, 35-45. 
27. Aricò, A.S.; Stassi, A.; Modica, E.; Ornelas, R.; Gatto, I.; Passalacqua, E.; Antonucci, V. Performance and degradation of high temperature polymer electrolyte fuel cell catalysts. J. Power Sources 2008, 178, 525-536.

28. Stassi, A.; Modica, E.; Antonucci, V.; Aricò, A.S. A half cell study of performance and degradation of oxygen reduction catalysts for application in low temperature fuel cells. Fuel Cells 2009, 9, 201-208.

29. Aricò, A.S.; Baglio, V.; Di Blasi, A.; Modica, E.; Antonucci, P.L.; Antonucci, V. Analysis of the high-temperature methanol oxidation behaviour at carbon-supported $\mathrm{Pt}-\mathrm{Ru}$ catalysts. J. Electroanal. Chem. 2003, 557, 167-176.

(C) 2015 by the authors; licensee MDPI, Basel, Switzerland. This article is an open access article distributed under the terms and conditions of the Creative Commons Attribution license (http://creativecommons.org/licenses/by/4.0/). 